Association between birth weight and adolescent

ONLINE systolic blood pressure in a caucasian birth cohort differs according to skin type, CRH promoter or 112-HSD2 genotype

T Dwyer, L Blizzard, B Patterson, A-L Ponsonby, K Martin, S Quinn, M M Sale, S $M$ Richards, R Morley, S Rich and J L Dickinson

Arch. Dis. Child. 2008;93;760-767; originally published online 2 May 2008; doi:10.1136/adc.2007.129122

Updated information and services can be found at:

http://adc.bmj.com/cgi/content/full/93/9/760

These include:

References This article cites 65 articles, 29 of which can be accessed free at: http://adc.bmj.com/cgi/content/full/93/9/760\#BIBL

Rapid responses You can respond to this article at: http://adc.bmj.com/cgi/eletter-submit/93/9/760

Email alerting Receive free email alerts when new articles cite this article - sign up in the box at service the top right corner of the article

Notes

To order reprints of this article go to:

http://journals.bmj.com/cgi/reprintform

To subscribe to Archives of Disease in Childhood go to:

http://journals.bmj.com/subscriptions/ 


\title{
Association between birth weight and adolescent systolic blood pressure in a caucasian birth cohort differs according to skin type, CRH promoter or $11 \beta$ - HSD2 genotype
}

\author{
T Dwyer ${ }^{1,2}$ L Blizzard, ${ }^{1}$ B Patterson, ${ }^{1}$ A-L Ponsonby, ${ }^{1,2}$ K Martin, ${ }^{1}$ S Quinn, ${ }^{1}$ M M Sale, ${ }^{1,3}$ \\ S M Richards, ${ }^{1}$ R Morley, ${ }^{2,4}$ S Rich, ${ }^{1,3} \mathrm{~J} \mathrm{~L} \mathrm{Dickinson}^{1}$
}

\begin{abstract}
${ }^{1}$ Menzies Research Institute, University of Tasmania, Hobart, Tasmania, Australia; ${ }^{2}$ Murdoch Childrens Research Institute, Royal Children's Hospital, Parkville, Victoria, Australia; ${ }^{3}$ Department of Public Health Sciences University of Virginia School of Medicine

Charlottesville, VA, USA;

${ }^{4}$ University of Melbourne Department of Paediatrics, Royal Children's Hospital, Parkville, Victoria, Australia
\end{abstract}

Correspondence to:

Professor T Dwyer, Murdoch Childrens Research Institute, Royal Children's Hospital,

Parkville, Victoria 3052 , Australia; terry.dwyer@mcri. edu.au

Accepted 17 March 2008 Published Online First 2 May 2008

\section{ABSTRACT}

Objective: To examine whether the inverse association between birth weight and blood pressure varies by skin pigmentation and/or related genotypes.

Study design: 671 children from a predominantly caucasian birth cohort were followed-up to adolescence (mean (SD) age $14.4(0.64)$ ).

Methods: Data on birth weight, socioeconomic status, maternal antenatal smoking, adolescent blood pressure and polymorphisms of candidate genes were obtained and analysed by multiple linear regression.

Results: An increase in birth weight of $1 \mathrm{~kg}$ was associated with an non-significant difference in adolescent systolic blood pressure of $-0.53 \mathrm{~mm} \mathrm{Hg}(95 \% \mathrm{Cl}-$ 1.72 to 0.66$)$ per $\mathrm{kg}$ after adjustment for child age and cohort entry criteria. The inverse association between birth weight and systolic blood pressure was stronger for those with darker skin ( $\geqslant 2 \%$ melanin) (difference in effect, $p=0.02$ ), those with more copies of the $C$ allele of corticotropin-releasing hormone (CRH) $+\mathrm{T} 1273 \mathrm{C}$ $(p=0.06)$, and those with more copies of the short $(\leqslant 236 \mathrm{bp})$ form of the $11 \beta-H S D 2\{C A\} n_{\text {repeat }}$ microsatellite $(p=0.03)$.

Conclusions: These findings add to the evidence that cortisol-related pathways may account for at least part of the observed birth weight-blood pressure associations.

An extensive body of research has shown that birth weight is related to adverse outcomes such as hypertension, risk of coronary heart disease and type 2 diabetes, with smaller babies having greater risk in later life. ${ }^{2}$ The underlying mechanisms are still not clear, but genetic factors associated with both fetal growth restriction and increased risk of cardiovascular disease may be involved. ${ }^{3}$

There is currently considerable interest in this link because of the rapidly increasing burden of cardiovascular and metabolic disease in developing countries, where low birth weight and growth restriction of infants at birth are common. Further, it is likely that the prevalence of the relevant genotypes may vary by race. African-Americans, Aborigines, Polynesians and people from the Indian subcontinent have a higher risk of hypertension, coronary heart disease and type 2 diabetes than caucasians. ${ }^{47}$ Some of these higher-risk groups have genotypes/phenotypes associated with longterm adaptation to living in warm climates near the equator, including an increase in skin pigmentation. In evolutionary terms, it has been proposed

\section{What is already known on this topic}

- Low birth weight has been associated with higher blood pressure in adult life.

- Glucocorticoids and the underlying hypothalamic-pituitary-adrenal axis may account for at least part of the observed birth weight-blood pressure associations.

\section{What this study adds}

- The inverse birth weight-blood pressure association varies by two cortisol-related genes, CRH promoter and $11 \beta-H S D 2$ genotype.

- The inverse birth weight-blood pressure association also varies by skin pigmentation in a caucasian population.

that famine may have forced selection for thrifty fat-storing genes among generations. ${ }^{8}$ Similarly, polymorphisms associated with retaining sodium, such as the angiotensinogen gene (AGT) M235T polymorphism, may have been beneficial for those living in warmer climates. ${ }^{8}$ This evolutionary perspective raises the question of whether genes associated with darker skin pigmentation may potentiate the association between low birth weight and adverse cardiovascular outcomes, an issue of public health significance. ${ }^{29}$ There is conflicting evidence about the relative strength of the association between birth weight and systolic blood pressure (SBP) in black versus white children or adults. ${ }^{10-13}$ These findings may be confounded by sociocultural factors related to skin pigmentation because people with different skin pigmentation may live in different sociocultural conditions. No study to date has examined the interaction between measured skin pigmentation and birth weight in relation to later sequelae in a relatively homogeneous ethnic group where genetic associations can be examined free of cultural confounding.

Candidate genes that may modify the association between low birth weight and blood pressure include those that meet the following four criteria: (1) have relevant biological functional effects; (2) are related 
Table 1 Characteristics of subjects at birth and at adolescent follow-up in 2002-4

\begin{tabular}{|c|c|c|c|}
\hline & $\begin{array}{l}\text { Males } \\
(\mathrm{n}=470)\end{array}$ & $\begin{array}{l}\text { Females } \\
(\mathrm{n}=203)\end{array}$ & $\begin{array}{l}\text { All subjects } \\
(n=673)\end{array}$ \\
\hline Birth weight in 1988 or $1989(\mathrm{~g})^{*}$ & $3338(702)$ & $2867(757)$ & $3204(743)$ \\
\hline Age in 2002-4 (years) & $14.43(0.65)$ & $14.52(0.62)$ & $14.45(0.64)$ \\
\hline Cutaneous melanin in 2002-4 (\%) & $1.47(1.53)$ & $1.77(1.51)$ & $1.56(1.53)$ \\
\hline $\begin{array}{l}\text { Systolic blood pressure in 2002-4 } \\
(\mathrm{mm} \mathrm{Hg})\end{array}$ & $109.6(10.7)$ & $108.4(10.5)$ & $109.2(10.7)$ \\
\hline $\begin{array}{l}\text { Diastolic blood pressure in 2002-4 } \\
\text { (mm Hg) }\end{array}$ & $55.7(6.3)$ & $58.0(6.5)$ & $56.4(6.5)$ \\
\hline Height in 2002-4 (cm) & $166.8(8.4)$ & $159.6(6.3)$ & $164.4(8.4)$ \\
\hline Weight in $2002-4(\mathrm{~kg})$ & $59.1(14.0)$ & $56.6(11.4)$ & $58.4(13.3)$ \\
\hline
\end{tabular}

to cardiovascular or metabolic outcomes; (3) are related to birth size or modify the association between birth size and adverse outcomes; (4) are related to skin pigmentation or differ across racial groups with differing skin pigmentation. In this report, we have focused on polymorphisms of the eight genes shown in table 2. Detailed information is provided in the Appendix, but genes that met our criteria were (i) angiotensin I-converting enzyme (ACE) ${ }^{14-19}$ (ii) AGT, ${ }^{20-24}$ (iii) apolipoprotein E (APOE), ${ }^{25-27}$ (iv) paraoxonase 2 (PON2) polymorphism, ${ }^{28} 29$ (v) proinsulin converting enzyme 1 (PC1), ${ }^{30-34}$ (vi) proopiomelanocortin

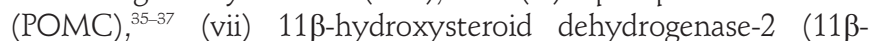
HSD2) $)^{38-41}$ and (viii) corticotropin-releasing hormone $(\mathrm{CRH}){ }^{42-47}$

The three cortisol-related genes (POMC, CRH, 11 $\beta$-HSD2) are of particular interest because there has been accumulating evidence since the inception of this study that glucocorticoids and the underlying hypothalamic-pituitary-adrenal (HPA) axis may account for at least part of the observed birth weightblood pressure associations. ${ }^{48} 49$

We have previously reported an inverse association between birth weight and childhood blood pressure in a follow-up of predominantly caucasian infants. ${ }^{50} 51$ There are unlikely to be major socioeconomic differences associated with skin pigmentation. We aimed to examine how the birth weight-blood pressure association varied by skin pigmentation. Further, we aimed to examine how the birth weight-blood pressure association varied by selected genetic polymorphisms, particularly those involved in cortisol-related pathways.

\section{METHODS \\ Subjects}

During the years 1988-1995, 10569 children were recruited soon after birth into the Tasmanian Infant Health Study, which had been established to investigate sudden infant death syndrome. ${ }^{52}$ The selection of eligible singleton subjects was based on scores allocated for each of six risk factors for sudden infant death syndrome (young maternal age, male infant, low birth weight, month of birth, maternal intention to bottle feed, and duration of the second stage of labour). ${ }^{52}$ Cohort eligibility was automatic for multiple births. Of the 1498 eligible infants born during 1988 or 1989 in southern Tasmania (a defined geographical region), 1443 (96.3\%) were recruited into the Tasmanian Infant Health Study. They included 1283 singletons, of whom 1028 were traced to the enrolment list of a school in southern Tasmania in 1996 (1988 cohort) or 1997 (1989 birth cohort), and 779 participated in follow-up studies during those years. ${ }^{51}{ }^{53}$ In $2002,87.5 \%(682 / 779)$ of the participants in 1996-7 were retraced in adolescence to an address in southern
Tasmania, and $98.7 \%(673 / 682)$ of those retraced subsequently participated in this further study. They represented $52.5 \%$ (673/ 1283) of the total pool of eligible singletons in the 1988 and 1989 birth cohorts.

This study was approved by the Human Research Ethics Committee (Tasmania), and parental written consent was obtained.

\section{Measurements}

At birth or early infant life

Routinely collected obstetric data (gestational age in completed weeks, placental weight, birth weight, crown-to-heel length, head circumference) were extracted from the infant's hospital records at birth. Secondly, the study nurses administered a questionnaire to their mothers in an in-hospital interview soon after birth, and direct measurements of the infants were made at that time. ${ }^{52}$

\section{In childhood}

Children who provided informed consent underwent measurements of anthropometrics, blood pressure, blood chemistry and lifestyle factors at follow-up in 1996 or $1997 . .^{153}$

\section{In adolescence}

Blood pressure was measured three times using a Critikon Dinamap Adult/Pediatric Vital Signs Monitor or was determined elsewhere. Weight was measured without shoes or heavy clothing using bathroom scales that were calibrated daily using known weights. Skin reflectance was measured using a Minolta spectrophotometer at the upper inner arm, a site exposed to relatively little sun. The reflectance readings at wavelengths of $400 \mathrm{~nm}$ and $420 \mathrm{~nm}$ were used to calculate the percentage concentration of cutaneous melanin at that site using the method described in detail elsewhere. ${ }^{54}$

\section{Genetic analyses \\ DNA collection}

Duplicate buccal mucosa swabs were collected by brushing inside the cheek with Gentra PureGene (Gentra Systems, Minneapolis, MN, USA) collection brushes which were placed in lysis solution immediately afterwards. In total, 671 samples were collected, but DNA quality and quantity was not adequate in some samples (table 2).

\section{Genotyping}

A conservative substitution in the $\mathrm{CRH}$ promoter at position +1273 (CRH+T1273C) was detected as described by GonzalezGay et $a l^{55}$ Single base substitutions (A to $\mathrm{G}$ in the PON2 gene at codon 148 (PON2 Ala148Gly); C to $\mathrm{T}$ at codon 235 of the AGT gene (AGT Met235Thr); $\mathrm{A}$ to $\mathrm{C}$ at codon 121 in plasma cell membrane glycoprotein PC1 (PC1 Lys121GIn)) were detected as described by Hegele et al, ${ }^{28}$ Russ et $a^{56}$ and Kubaszek et al, ${ }^{33}$ respectively. Two substitutions ( $C$ to $\mathrm{T}$ at codon 112 and $\mathrm{C}$ to $\mathrm{T}$ at codon 158 in APOE (APOE Cys112Arg, Cys158Arg)) were detected as described by Ossendorf and Prellwitz. ${ }^{57}$ For the ACE gene, the insertion/deletion alleles (ACE I/D) in intron 16 were detected as described by Chiu and McCarthy. ${ }^{58}$ The POMC insertion/deletion alleles at exon 3 (POMC I/D), described by Morris et al, ${ }^{59}$ were amplified using a Hex-labelled forward primer, POMCF 5'AGTACGTCATGGGCCACTTC-3', and an unlabelled reverse primer, POMCR 5'-CATGGAGTAGGAGCGCTTG-3'. Products were then sized on an ABI PRISM 310 Genetic Analyser 
Table 2 Mean levels of birth weight, systolic blood pressure (SBP) and melanin density of adolescent subjects classified by genotype

\begin{tabular}{|c|c|c|c|c|}
\hline Genotype & $\begin{array}{l}\text { No of } \\
\text { subjects }\end{array}$ & $\begin{array}{l}\text { Birth weight } \\
\text { (g) }\end{array}$ & $\begin{array}{l}\text { SBP } \\
\text { (mm Hg) }\end{array}$ & $\begin{array}{l}\text { Cutaneous } \\
\text { melanin } \\
(\%)\end{array}$ \\
\hline \multicolumn{5}{|c|}{ Angiotensin 1-converting enzyme insertion/deletion (ACE I/D) } \\
\hline $\mathrm{D} / \mathrm{D}$ & 190 & $3203(51)$ & $110.8(0.74)$ & $1.48(0.11)$ \\
\hline $\mathrm{l} / \mathrm{D}$ & 308 & $3157(40)$ & $109.4(0.57)$ & $1.46(0.09)$ \\
\hline $\mathrm{l} / \mathrm{I}$ & 144 & $3269(58)$ & $109.7(0.84)$ & $1.66(0.13)$ \\
\hline Linear trend & & $p=0.47$ & $p=0.28$ & $p=0.31$ \\
\hline \multicolumn{5}{|c|}{ Angiotensinogen Met235Thr (AGT Met235Thr) } \\
\hline Met/Met & 158 & $3222(55)$ & $110.4(0.80)$ & $1.36(0.13)$ \\
\hline $\mathrm{Met} / \mathrm{Thr}$ & 200 & $3206(49)$ & $109.3(0.71)$ & $1.56(0.11)$ \\
\hline $\mathrm{Thr} / \mathrm{Thr}$ & 65 & $3222(87)$ & $108.2(1.22)$ & $1.67(0.20)$ \\
\hline Linear trend & & $p=0.94$ & $p=0.13$ & $p=0.14$ \\
\hline \multicolumn{5}{|l|}{ Apoprotein E (ApoE) } \\
\hline$\varepsilon 4 / \varepsilon 4$ & 18 & $3298(165)$ & $107.5(2.3)$ & $1.81(0.37)$ \\
\hline$\varepsilon 4 / \varepsilon 3$ & 148 & $3084(59)$ & $109.5(0.8)$ & $1.39(0.13)$ \\
\hline$\varepsilon 4 / \varepsilon 2$ & 16 & $3057(181)$ & $117.2(2.7)$ & $0.77(0.37)$ \\
\hline$\varepsilon 3 / \varepsilon 3$ & 398 & $3215(36)$ & $109.8(0.5)$ & $1.61(0.08)$ \\
\hline$\varepsilon 2 / \varepsilon 2$ or $\varepsilon 2 / \varepsilon 3$ & 79 & $3334(78)$ & $109.6(1.1)$ & $1.46(0.17)$ \\
\hline$\varepsilon 2 / \varepsilon 2$ & 4 & $2851(374)$ & $109.7(5.0)$ & $0.63(0.73)$ \\
\hline Difference of means & & $p=0.14$ & $p=0.11$ & $p=0.13$ \\
\hline \multicolumn{5}{|c|}{ Paraoxonase 2 (Pon2 Ala148Gly) } \\
\hline Ala/Ala & 365 & $3185(38)$ & $109.7(0.5)$ & $1.55(0.08)$ \\
\hline Ala/Gly & 237 & $3183(47)$ & $110.5(0.7)$ & $1.46(0.10)$ \\
\hline Gly/Gly & 53 & $3254(98)$ & $108.1(1.4)$ & $1.62(0.22)$ \\
\hline Linear trend & & $p=0.66$ & $p=0.76$ & $p=0.86$ \\
\hline \multicolumn{5}{|c|}{ Plasma cell membrane glycoprotein-1 (PC1 Lys121Gln) } \\
\hline Ala/Ala & 487 & $3228(32)$ & $109.8(0.5)$ & $1.52(0.07)$ \\
\hline Ala/Gly & 167 & $3090(56)$ & $110.0(0.8)$ & $1.50(0.12)$ \\
\hline Gly/Gly & 11 & $3145(216)$ & $109.0(3.0)$ & $1.55(0.47)$ \\
\hline Linear trend & & $p=0.04$ & $p=0.99$ & $p=0.91$ \\
\hline \multicolumn{5}{|c|}{ Corticotropin-releasing hormone (CRH+T1273C) } \\
\hline $\mathrm{T} / \mathrm{T}$ & 527 & $3195(31)$ & $109.7(0.4)$ & $1.49(0.06)$ \\
\hline$T / C$ & 107 & $3169(69)$ & $110.9(1.0)$ & $1.55(0.15)$ \\
\hline $\mathrm{C} / \mathrm{C}$ & 10 & $3069(229)$ & $111.4(3.3)$ & $1.97(0.51)$ \\
\hline Linear trend & & $p=0.57$ & $p=0.23$ & $p=0.42$ \\
\hline \multicolumn{5}{|c|}{ Proopiomelanocortin exon 3 insertion/deletion (POMC I/D) } \\
\hline $\mathrm{D} / \mathrm{D}$ & 597 & $3173(29)$ & $110.1(0.4)$ & $1.50(0.06)$ \\
\hline $\mathrm{D} / \mathrm{l}$ & 70 & $3342(84)$ & $107.6(1.2)$ & $1.67(0.19)$ \\
\hline l/l & 3 & $2574(449)$ & $104.2(5.5)$ & $2.97(0.95)$ \\
\hline Linear trend & & $p=0.24$ & $p=0.03$ & $p=0.16$ \\
\hline \multicolumn{5}{|c|}{$11 \beta$-Hydroxysteriod dehydrogenase CA repeat $\left(11 \beta-H S D 2\{C A\}_{n}\right)$} \\
\hline $238+/ 238+$ & 576 & $3187(30)$ & $109.9(0.4)$ & $1.52(0.06)$ \\
\hline $238+/<238$ & 76 & $3241(82)$ & $108.8(1.2)$ & $1.42(0.18)$ \\
\hline$<238 /<238$ & 6 & $2756(310)$ & $120.0(4.6)$ & $2.69(0.68)$ \\
\hline Linear trend & & $p=0.88$ & $p=0.71$ & $p=0.67$ \\
\hline
\end{tabular}

Values are mean (SE) (ie, sample mean (estimated SE)).

(Applied Biosystems, Foster City, CA, USA). HSD2 CA repeat alleles $\left(11 \beta-H S D 2\{C A\}_{n}\right)$ were amplified using a Fam-labelled forward primer, HSDF 5'-GTGTGCAAGATGTGGGTGAC-3', and an unlabelled reverse primer, HSDR 5'CCTGCTGAGGAGGGGTACTT-3'. Reaction conditions and sizing were the same as for POMC. The $11 \beta-H S D 2\{C A\}_{n}$ microsatellite varied from $230 \mathrm{bp}$ to $248 \mathrm{bp}$ and, by comparison, corresponded to alleles 141-159 bp, as reported by Agarwal et al, ${ }^{60}$ and with alleles $140-158 \mathrm{bp}$, as reported by Lavery et al. ${ }^{61} \mathrm{~A}$ microsatellite with a low repeat number of $236 \mathrm{bp}$ and below was classified as short and denoted as $11 \beta-H S D 2\{C A\}_{n}=$ short. Reduced allelic repeat length has previously been associated with reduced $11 \beta$-HSD2 activity. ${ }^{38}$

We provide the OMIM reference, ${ }^{62}$ reference NCBI database SNP ID ${ }^{63}$ or GenBank accession code $^{64}$ for the genetic polymorphisms studied: (i) ACE, 106180, rs13447447; (ii) AGT, 106150, rs699; (iii) APOE 107741, rs429358, rs7412; (iv) PON2, 602447, rs12026; (v) PC1, 173335, rs1044498; (vi) POMC, 176830, rs10654394; (vii) 11ß-HSD2, 218030, GenBank AF071493; (viii) CRH, 122560, GenBank x67661.

\section{Data analysis}

Means and standard deviations of variables were calculated from the original data or, where required, those data rescaled by appropriate transformations. Melanin concentrations were dichotomised at $2 \%$ for stratified analyses. This cut-off lies near the median for caucasian adults. ${ }^{54}$ The strength of associations between variables are summarised by correlation coefficients and by linear regression coefficients. Linear trend was assessed from the test of the regression coefficient of a 


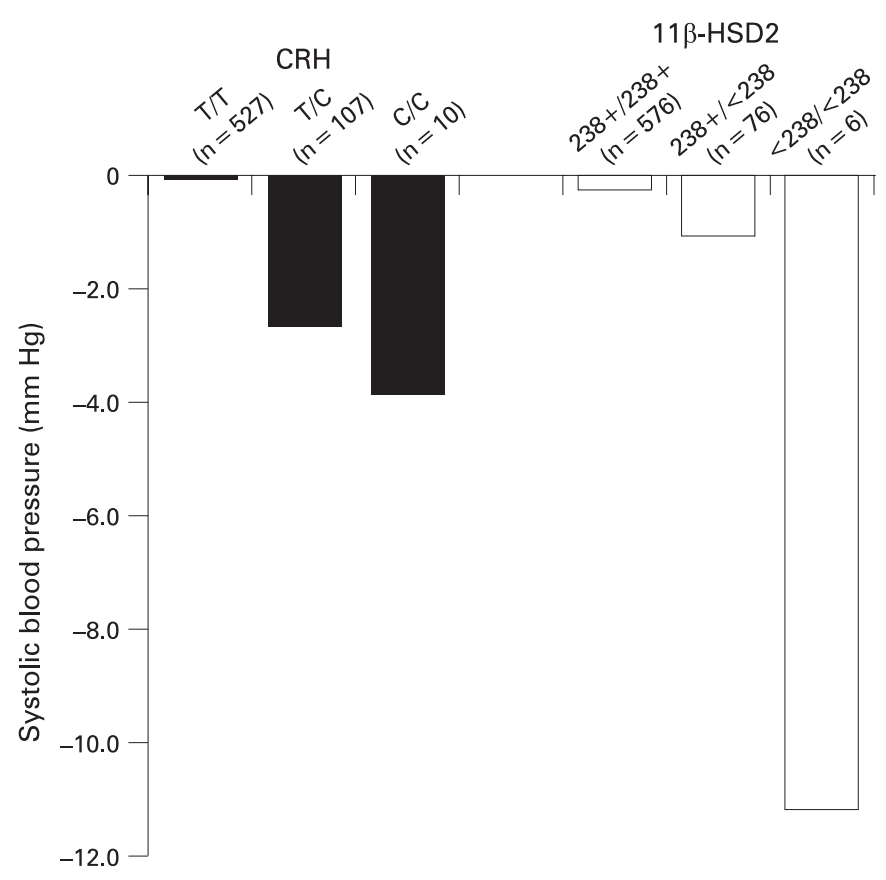

Figure 1 In the regression of adolescent systolic blood pressure (SBP) on birth weight, independently estimated differences in SBP associated with a $1 \mathrm{~kg}$ difference in birth weight for subjects classified by $\mathrm{CRH}$ and $11 \beta$-HSD2 genotype. The interactions between birth weight and the genes expressed on a linear (additive) scale were significant for both CRH $(p=0.04)$ and $11 \beta-H S D 2(p=0.01)$.

single predictor taking rank scores for ordered categories. In the regression of outcome factors on genotype, a binary $(0 / 1)$ variable was used to represent each specific genotype other than the most common (reference group) genotype, with trend assessed using a single predictor coded for additive effects - that is, taking consecutive integer scores for genotypes ordered in decreasing frequency of the most common allele.

Regression models included terms for subject age at blood pressure measurement and for cohort selection factors (mother's age, mother's intention to breast feed, duration of second stage labour, and child sex) to remove confounding that selection based on these factors may have introduced. Birth weight, another selection factor, was the main study factor and was included in most analyses. Interaction between birth weight and melanin density, between birth weight and genotype, and between genotypes was assessed from the coefficient and standard error of an interaction term formed from the product of the relevant covariates. ${ }^{65}$ An extensive array of questionnaire-based measures of parental, family and domestic factors in infancy and childhood was available to control for confounding by socioeconomic situation.

\section{RESULTS \\ General characteristics}

Table 1 shows subject characteristics. The median of the measurements of cutaneous melanin was $1.5 \%$, and the interquartile range (25th to 75 th centile) was $0.3-2.9 \%$. The highest melanin concentration recorded was $5.1 \%$, and $94 \%$ (627/667) of the sample had a value less than $4 \%$, consistent with a caucasian population. Similar proportions of boys (188/ $470)$ and girls (82/202) had more than $2 \%$ melanin in their skin $(\mathrm{p}=0.95)$.

Birth weight, melanin density and SBP classified by genotype Table 2 shows mean levels of birth weight and adolescent SBP for each of the genotypes.

\section{Inverse association between birth weight and SBP in adolescence}

In regression models with adjustment for age at examination and cohort selection factors, birth weight was weakly inversely associated with adolescent SBP. An increase in birth weight of $1 \mathrm{~kg}$ was associated with a change in SBP of $-0.53 \mathrm{~mm} \mathrm{Hg}(95 \%$ CI -1.72 to $0.66, p=0.33)$. After adjustment for current height and weight, a $1 \mathrm{~kg}$ increase in birth weight was associated $(p<0.01)$ with a change in SBP of $-1.87 \mathrm{~mm} \mathrm{Hg}$ (95\% CI-3.01 to -0.73 ). Associations were similar for boys and girls.

\section{Stronger association of birth weight with SBP in those with darker skin pigmentation}

Darker skin pigmentation modified the association between birth weight and adolescent SBP (interaction between birth weight and increasing continuous melanin density, $p=0.03$ ). To best illustrate this interaction, we dichotomised the continuous melanin measurements at $2 \%$. For the $40 \%$ (267/

Table 3 Jointly estimated differences in systolic blood pressure (SBP) associated with a $1 \mathrm{~kg}$ difference in birth weight in the regression of adolescent SBP on birth weight: analysis of interaction effects showing that the change in SBP becomes more negative with darker skin type ( $\geqslant 2 \%$ melanin), each additional copy of the $\mathrm{CRH}+\mathrm{T} 1273 \mathrm{C}$ allele, and each additional copy of the shorter-sized $11 \beta-\mathrm{HSD} 2\{\mathrm{CA}\}_{\mathrm{n}}$ microsatellite

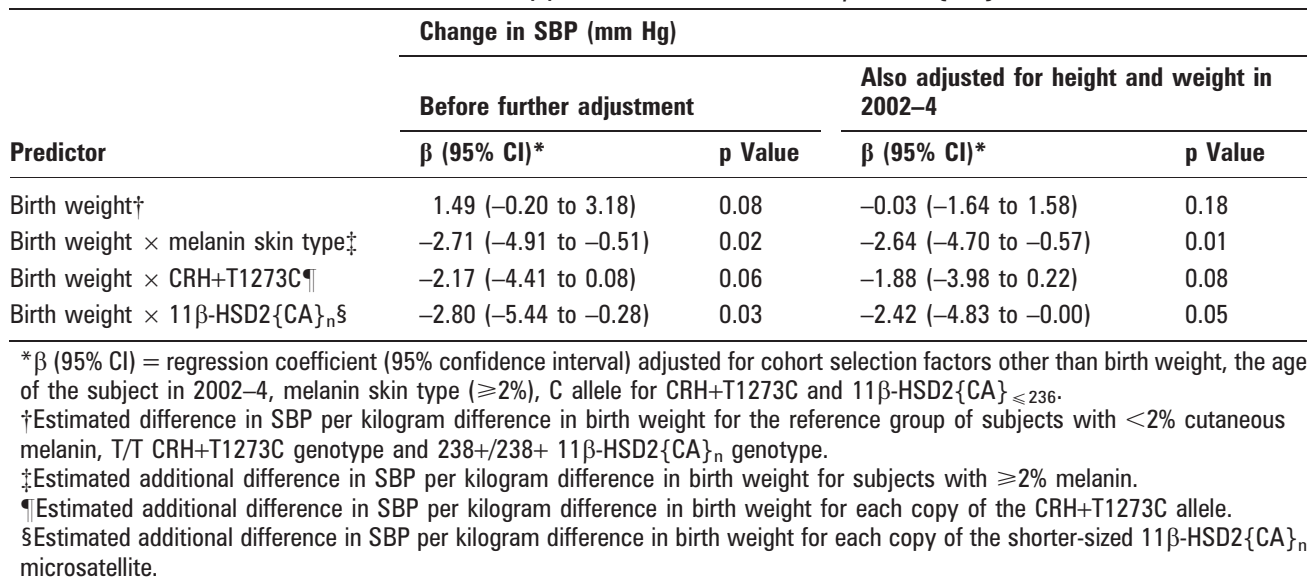


Table 4 Estimated differences in systolic blood pressure (SBP) associated with a $1 \mathrm{~kg}$ difference in birth weight for cutaneous melanin, $\mathrm{CRH}+\mathrm{T} 1273 \mathrm{C}$ or $11 \beta-\mathrm{HSD} 2\{\mathrm{CA}\}_{\mathrm{n}}$ genotype separately in the regression of adolescent SBP on birth weight; effect of adjustment for gestational age

\begin{tabular}{|c|c|c|c|}
\hline \multirow[b]{2}{*}{ Subjects characterised by } & \multirow[b]{2}{*}{$\mathrm{No}^{*}$} & \multicolumn{2}{|c|}{ Difference in SBP $(\mathrm{mm} \mathrm{Hg}) \dagger$} \\
\hline & & $\begin{array}{l}\text { Before further } \\
\text { adjustment }\end{array}$ & $\begin{array}{l}\text { Adjusted also for } \\
\text { gestational age }\end{array}$ \\
\hline \multicolumn{4}{|l|}{ Cutaneous melanin } \\
\hline$<2 \%$ melanin (lighter) & 267 & $0.42(-1.06$ to 1.89$)$ & $1.31(-0.44$ to 3.05$)$ \\
\hline$\geqslant 2 \%$ melanin (darker) & 400 & $-2.22(-3.91$ to -0.53$)$ & $-1.18(-3.20$ to 0.83$)$ \\
\hline Interaction & 667 & $-2.64(-0.54$ to -4.74$)$ & $-2.49(-4.59$ to -0.39$)$ \\
\hline \multicolumn{4}{|l|}{ CRH+T1273C genotype } \\
\hline $\mathrm{T} / \mathrm{T}$ & 523 & $-0.02(-1.40$ to 1.39$)$ & $0.78(-0.94$ to 2.50$)$ \\
\hline $\mathrm{T} / \mathrm{C}$ & 106 & $-2.62(-5.31$ to 0.06$)$ & $-1.77(-4.44$ to 0.89$)$ \\
\hline $\mathrm{C} / \mathrm{C}$ & 9 & $-3.82(-11.22$ to 3.59$)$ & $-2.30(-9.95$ to 5.36$)$ \\
\hline Interaction & 638 & $-2.29(-4.53$ to -0.04$)$ & $-2.13(-4.38$ to 0.12$)$ \\
\hline \multicolumn{4}{|l|}{$11 \beta-H S D 2\{C A\}_{n}$ genotype } \\
\hline $238+/ 238+$ & 570 & $-0.24(-1.53$ to 1.04$)$ & $0.84(-0.83$ to 2.52$)$ \\
\hline $238+/<238$ & 76 & $-1.04(-3.94$ to 1.85$)$ & $-0.29(-3.27$ to 2.70$)$ \\
\hline$<238 /<238$ & 6 & $-11.19(-20.41$ to -1.97$)$ & $-9.82(-19.11$ to -0.52$)$ \\
\hline Interaction & 652 & $-3.08(-5.61$ to -0.56$)$ & $-3.29(-5.82$ to -0.77$)$ \\
\hline
\end{tabular}

*Number of subjects, which may differ slightly from those given elsewhere because of missing data on one or more of the adjustment factors.

$\dagger \beta(95 \% \mathrm{CI})=$ regression coefficient $(95 \%$ confidence interval) adjusted for cohort selection factors other than birth weight, and for the age of the subject in 2002-4.

667 ) of subjects with more than $2 \%$ melanin, an increase in birth weight of $1 \mathrm{~kg}$ was associated with a more than $2 \mathrm{~mm} \mathrm{Hg}$ reduction in SBP $(-2.12 \mathrm{~mm} \mathrm{Hg}(95 \% \mathrm{CI}-3.82$ to- 0.41$)$. For the remaining 60\% (400/667) lighter-skinned subjects with less than $2 \%$ melanin, the association was weaker $(0.42 \mathrm{~mm} \mathrm{Hg}$ (95\% CI -1.05 to 1.89 ), and the greater magnitude of the birth weightSBP association in those with darker skin was significant (difference in effect, $\mathrm{p}=0.01$ ).

\section{Modification of the birth weight-SBP association by CRH and 11及-HSD2 genotype}

With the genotypes expressed on a linear (additive) scale, we found significant interactions between birth weight and these two gene variants in the explanation of SBP: $p=0.04$ for any $C$ allele for CRH+T1273C $\times$ birth weight and $p=0.01$ for $11 \beta$ HSD2 $\{C A\}_{n}=$ short genotype $\times$ birth weight (fig 1$)$. For each of these, the inverse association between birth weight and SBP was strongest for subjects with two copies for the least common alleles (fig 1).

\section{Independent modification of the association between birth weight and SBP by dark skin pigmentation or CRH and 11ß-HSD2 genotype}

Table 3 shows that the interaction between each of these three factors and birth weight on adolescent SBP persisted when the effects were considered in the same model. This indicates that interaction between birth weight and each of these cortisolrelated genes or dark skin pigmentation could not be accounted for by the other interactions. Further adjustment for adolescent weight and height marginally reduced these interactions, with the greatest change occurring in the estimated interaction between birth weight and CRH+T1273C genotype $(\beta=-2.42$, $p=0.05$ after adjustment).

\section{Additional analyses}

We conducted additional analyses to further investigate the potential influence of gestation and socioeconomic confounding on these main findings and we also examined gene epistasis.
Table 4 shows that the patterns observed for a stronger birth weight-adolescent SBP association by darker skin, genotype or $11 \beta-H S D 2\{C A\}_{n}=$ short genotype persisted after adjustment for gestation. In addition, there was no evidence of interaction between gestation length and darker skin $(p=0.17)$, CRH+T1273C genotype $(p=0.87)$, or $11 \beta-H S D 2\{C A\}_{n}=$ short genotype $(p=0.45)$ with regard to adolescent SBP. Thus gestation did not appear to explain the three interactions observed in table 3 .

Melanin density in this sample did not appear to be a marker for socioeconomic status. Darker skin was weakly associated with birth weight $(r=-0.09, p=0.02)$ and adolescent SBP $(r=-$ $0.10, p=0.01)$ but not with household income $(r=0.01$, $p=0.80)$, maternal education $(r=-0.04, p=0.27)$, the number of persons sharing the household $(r=-0.05, p=0.27)$ or the density of persons per room $(r=-0.03, p=0.49)$. Nor was it associated with other recorded factors that have been linked to lower socioeconomic status, namely private health insurance, teenage motherhood or paternal unemployment (data not shown.) Similarly, markers of lower socioeconomic status were not associated with the CRH+T1273C variant or $11 \beta$ HSD2 $\{C A\}_{n}=$ short (data not shown). We further adjusted for any maternal antenatal smoking, but this did not alter the results in tables 3 and 4 .

Because both CRH and $11 \beta-H S D 2$ are part of signalling via the HPA axis, we hypothesised that there may be gene-gene interaction, but this was not evident (data not shown).

\section{DISCUSSION}

In this follow-up study, we tested the hypothesis that the relationship between birth weight and adolescent SBP in a caucasian sample differs by skin pigmentation and associated candidate genotypes. We found that the relationship between birth weight and adolescent blood pressure was modified by three factors: greater skin pigmentation of the upper inner arm ( $\geqslant 2 \%$ melanin), the $\mathrm{C}$ allele of the $\mathrm{CRH}+\mathrm{T} 1273 \mathrm{C}$ allele, and short allele of the $11 \beta-H S D 2\{\mathrm{CA}\}_{\mathrm{n}}$ microsatellite.

Markers of lower socioeconomic status were not associated with skin pigmentation or $\mathrm{CRH}+\mathrm{T} 1273 \mathrm{C}$ or $11 \beta-\mathrm{HSD} 2\{\mathrm{CA}\}_{\mathrm{n}}$ 
genotype, reducing the likelihood that these factors were markers of an adverse sociocultural environment that, in itself, may contribute to the birth weight-blood pressure association. Similarly, maternal antenatal smoking was not associated with these three characteristics, and adjustment for antenatal smoking did not alter the study findings in tables 3 and 4 . Further, as shown by the lack of association of these genes with melanin concentration, CRH+T1273C and $11 \beta-H S D 2\{\mathrm{CA}\}_{\mathrm{n}}$ genotype did not appear to be antecedents of skin pigmentation in this caucasian sample. The lack of association of ACE I/D and AGT Met235Thr with blood pressure is surprising, and suggests that the influence of these genes on blood pressure is via a pathway that is not associated with skin pigmentation.

The strengths of this study were: the sample was drawn from a relatively homogeneous caucasian population, reducing problems related to population stratification; the range of study measurements was comprehensive; the design was prospective. Because adjustment for adolescent weight may be inappropriate when studying the effect of birth weight on later outcomes if the putative effect is mediated by child growth or weight, ${ }^{66}$ results were provided without adjustment for child size, and further results with adjustment for adolescent height and weight were supplied as supplementary analyses.

Limitations of this study include the inability to assess the influence of darker skin pigmentation across a wider range of skin types, thus these results cannot be extrapolated beyond a caucasian population. Further, owing to the sample size and predominance of males and the analytical aim of assessing interactions, we were not able to examine in detail sex-specific effects, which may be important. However, no differences in the birth weight-blood pressure association were observed between females and males.

The findings in relation to CRH+T1273C and $11 \beta$ $\mathrm{HSD} 2\{\mathrm{CA}\}_{\mathrm{n}}$ genotype add to the growing evidence that glucocorticoids, mineralocorticoids and the underlying HPA axis may account for at least part of the observed birth weightblood pressure associations. ${ }^{48} 67$

Fetal exposure to cortisol is thought to reset the developing HPA axis, leading to raised cortisol in the offspring. ${ }^{67}$ Growthrestricted infants have higher cord blood cortisol, ${ }^{68}$ with increased HPA activity found in adulthood. ${ }^{49}$ In Jamaican children, a strong dose-response between fasting plasma cortisol and SBP at age 8-9 has been reported. ${ }^{48}$ Little work has been published on the effect of $\mathrm{T}$ to $\mathrm{C}$ polymorphism in the $\mathrm{CRH}$ promoter, and it has only recently been established that $\mathrm{CRH}$ reactivity varies between the promoter alleles. ${ }^{42}$ However, a possible link to dysregulated HPA activity exists. ${ }^{44} 11 \beta$ $\mathrm{HSD} 2\{\mathrm{CA}\}_{\mathrm{n}}$ genotype is linked to increased cortisol signalling in mineralocorticoid-sensitive tissues. ${ }^{38}$ Given that both $\mathrm{CRH}$ and $11 \beta$-HSD2 genes are involved in cortisol-related pathways, we assessed epistasis between the two gene variants, but genegene interaction was not evident. Increasing the likelihood that the cortisol-related pathways are important, a third gene polymorphism, the I allele of POMC, was associated with lower blood pressure (table 2), consistent with the known effects of the POMC I form being associated with reduced adrenocorticotrophin-related hypertension. ${ }^{69}$

Our findings suggest that the inverse association between birth weight and adolescent SBP varies by genotype. In particular, genes pertaining to cortisol-related pathways and skin pigmentation appeared important in this caucasian adolescent population. A strength of this study was that we had available a range of markers of socioeconomic status with which to evaluate potential sociocultural confounding, but a limitation is that non-caucasian populations were not studied. The findings have added to other evidence that cortisol-related pathways may at least partly underlie the inverse association between size at birth and later blood pressure.

Acknowledgements: We thank the research nurses who conducted the at-birth measurements, Carole Goff and Philippa Boon who undertook the tracing of the cohort and conducted field measurements, Michael Martin who assisted with tracing and fieldwork in 1996-7, Jenny Cochrane for long-term cohort data management including supervision of tracing and follow-up, the schools that provided facilities, and especially the children and families of children who participated in the study.

Funding: This study was funded by the National Health and Medical Research Council of Australia. The Tasmanian Infant Health Survey was funded by the National Health and Medical Research Council of Australia, US National Institutes of Health (grant 001 HD28979-01A1), Tasmanian State Government, Australian Rotary Health Research Fund, Sudden Infant Death Syndrome Research Foundation, National Sudden Infant Death Syndrome Council of Australia, Community Organizations' support program of the Department of Human Services and Health, Zonta International, Wyeth Pharmaceuticals and Tasmanian Sanatoria After-Care Association. A-LP was supported by a National Health and Medical Research Council PHRDC Fellowship. RM was supported by VicHealth (The Victorian Health Promotion Foundation). MMS is supported by a Career Development Award from the American Diabetes Association.

Competing interests: None.

Ethics approval: Ethics approval was obtained.

\section{REFERENCES}

1. Davies AA, Smith GD, May MT, et al. Association between birth weight and blood pressure is robust, amplifies with age, and may be underestimated. Hypertension 2006;48:431-6.

2. Prentice AM, Moore SE. Early programming of adult diseases in resource poor countries. Arch Dis Child 2005;90:429-32.

3. Frayling TM, Hattersley AT. The role of genetic susceptibility in the association of low birth weight with type 2 diabetes. Br Med Bull 2001;60:89-101.

4. Braun B, Zimmermann MB, Kretchmer N, et al. Risk factors for diabetes and cardiovascular disease in young Australian aborigines. A 5-year follow-up study. Diabetes Care 1996;19:472-9.

5. Hegele RA. Genetic prediction of atherosclerosis: lessons from studies in native Canadian populations. Clin Chim Acta 1999;286:47-61.

6. Miller GJ, Wachter C. Adult male all-cause, cardiovascular and cerebrovascular mortality in relation to ethnic group, systolic blood pressure and blood glucose concentration in Trinidad, West Indies. Int J Epidemiol 1988;17:62-9.

7. Whitty CJ, Brunner EJ, Shipley MJ, et al. Differences in biological risk factors for cardiovascular disease between three ethnic groups in the Whitehall II study. Atherosclerosis 1999;142:279-86.

8. Kagawa Y, Yanagisawa Y, Hasegawa K, et al. Single nucleotide polymorphisms of thrifty genes for energy metabolism: evolutionary origins and prospects for intervention to prevent obesity-related diseases. Biochem Biophys Res Commun 2002;295:207-22.

9. Yajnik C. Interactions of perturbations in intrauterine growth and growth during childhood on the risk of adult-onset disease. Proc Nutr Soc 2000;59:257-65.

10. Donker GA, Labarthe DR, Harrist RB, et al. Low birth weight and blood pressure at age 7-11 years in a biracial sample. Am J Epidemiol 1997;145:387-97.

11. Hemachandra $\mathbf{A H}$, Klebanoff MA, Furth SL. Racial disparities in the association between birth weight in the term infant and blood pressure at age 7 years: results from the collaborative perinatal project. J Am Soc Nephrol 2006;17:2576-81.

12. Mzayek F, Sherwin R, Fonseca V, et al. Differential association of birth weight with cardiovascular risk variables in African-Americans and Whites: the Bogalusa heart study. Ann Epidemiol 2004;14:258-64.

13. Hughson MD, Douglas-Denton R, Bertram JF, et al. Hypertension, glomerular number, and birth weight in African Americans and white subjects in the southeastern United States. Kidney Int 2006;69:671-8.

14. Cambien F, Leger J, Mallet C, et al. Angiotensin I-converting enzyme gene polymorphism modulates the consequences of in utero growth retardation on plasma insulin in young adults. Diabetes 1998;47:470-5.

15. Rigat B, Hubert C, Alhenc-Gelas F, et al. An insertion/deletion polymorphism in the angiotensin I-converting enzyme gene accounting for half the variance of serum enzyme levels. J Clin Invest 1990;86:1343-6.

16. Singer DR, Missouris CG, Jeffery S. Angiotensin-converting enzyme gene polymorphism. What to do about all the confusion [see comment]. Circulation 1996;94:236-9.

17. Ruiz J, Blanche $\mathrm{H}$, Cohen $\mathrm{N}$, et al. Insertion/deletion polymorphism of the angiotensin-converting enzyme gene is strongly associated with coronary hear disease in non-insulin-dependent diabetes mellitus. Proc Natl Acad Sci USA 1994:91:3662-5.

18. Kajantie E, Rautanen A, Kere J, et al. The effects of the ACE gene insertion/deletion polymorphism on glucose tolerance and insulin secretion in elderly people are modified by birth weight. J Clin Endocrinol Metab 2004;89:5738-41. 
19. Barley J, Blackwood A, Miller M, et al. Angiotensin converting enzyme gene I/D polymorphism, blood pressure and the renin-angiotensin system in Caucasian and Afro-Caribbean peoples. J Hum Hypertens 1996;10:31-5.

20. Bloem LJ, Manatunga AK, Tewksbury DA, et al. The serum angiotensinogen concentration and variants of the angiotensinogen gene in white and black children. $J$ Clin Invest 1995;95:948-53.

21. Sagnella GA, Rothwell MJ, Onipinla AK, et al. A population study of ethnic variations in the angiotensin-converting enzyme I/D polymorphism: relationships with gender, hypertension and impaired glucose metabolism. J Hypertens 1999;17:657-64.

22. Hegele RA, Ban MR, Busch CP, et al. Lipoprotein-genotype associations in Trinidadian neonates. Clin Biochem 1999;32:429-37.

23. Staessen JA, Ginocchio G, Wang JG, et al. Genetic variability in the renin-angiotensin system: prevalence of alleles and genotypes. J Cardiovasc Risk 1997;4:401-22.

24. Nakajima T, Jorde LB, Ishigami T, et al. Nucleotide diversity and haplotype structure of the human angiotensinogen gene in two populations [see comment]. Am J Hum Genet 2002;70:108-23.

25. Henry JA, Bolla M, Osmond C, et al. The effects of genotype and infant weight on adult plasma levels of fibrinogen, factor VII, and LDL cholesterol are additive. J Med Genet 1997;34:553-8.

26. Gregg RE, Ghiselli G, Brewer HB Jr. Apolipoprotein EBethesda: a new variant of apolipoprotein E associated with type III hyperlipoproteinemia. J Clin Endocrinol Metab 1983;57:969-74.

27. Gerdes LU, Klausen IC, Sihm I, et al. Apolipoprotein E polymorphism in a Danish population compared to findings in 45 other study populations around the world Genet Epidemiol 1992;9:155-67.

28. Hegele RA, Connelly PW, Scherer SW, et al. Paraoxonase-2 gene (PON2) G148 variant associated with elevated fasting plasma glucose in noninsulin-dependent diabetes mellitus. J Clin Endocrinol Metab 1997;82:3373-7.

29. Busch CP, Ramdath DD, Ramsewak S, et al. Association of PON2 variation with birth weight in Trinidadian neonates of South Asian ancestry. Pharmacogenetics 1999;9:351-6.

30. Kahn CR. Diabetes. Causes of insulin resistance [comment]. Nature 1995;373:384-5.

31. Pizzuti A, Frittitta L, Argiolas A, et al. A polymorphism (K1210) of the human glycoprotein PC-1 gene coding region is strongly associated with insulin resistance. Diabetes 1999:48:1881-4.

32. Meyre D, Bouatia-Naji N, Tounian A, et al. Variants of ENPP1 are associated with childhood and adult obesity and increase the risk of glucose intolerance and type 2 diabetes. Nat Genet 2005;37:863-7.

33. Kubaszek A, Markkanen A, Eriksson JG, et al. The association of the K1210 polymorphism of the plasma cell glycoprotein-1 gene with type 2 diabetes and hypertension depends on size at birth. J Clin Endocrinol Metab 2004;89:2044-7.

34. Hamaguchi $\mathbf{K}$, Terao $\mathrm{H}$, Kusuda $\mathrm{Y}$, et al. The PC-1 0121 allele is exceptionally prevalent in the Dominican Republic and is associated with type 2 diabetes. J Clin Endocrinol Metab 2004;89:1359-64.

35. Santoro N, del Giudice EM, Cirillo G, et al. An insertional polymorphism of the proopiomelanocortin gene is associated with fasting insulin levels in childhood obesity. J Clin Endocrinol Metab 2004;89:4846-9.

36. Krude $\mathbf{H}$, Biebermann H, Gruters A. Mutations in the human proopiomelanocortin gene. Ann N Y Acad Sci 2003;994:233-9.

37. Millington GW. Proopiomelanocortin (POMC): the cutaneous roles of its melanocortin products and receptors. Clin Exp Dermatol 2006;31:407-12.

38. White PC, Agarwal AK, Nunez BS, et al. Genotype-phenotype correlations of mutations and polymorphisms in HSD11B2, the gene encoding the kidney isozyme of 11 beta-hydroxysteroid dehydrogenase. Endocr Res 2000;26:771-80.

39. Wilson RC, Dave-Sharma S, Wei JO, et al. A genetic defect resulting in mild lowrenin hypertension. Proc Natl Acad Sci USA 1998;95:10200-5.

40. Lovati $\mathbf{E}$, Ferrari P, Dick B, et al. Molecular basis of human salt sensitivity: the role of the 11 beta-hydroxysteroid dehydrogenase type 2. J Clin Endocrinol Metab 1999;84:3745-9.

41. Schoof E, Girstl M, Frobenius W, et al. Decreased gene expression of 11 betahydroxysteroid dehydrogenase type 2 and 15-hydroxyprostaglandin dehydrogenase in human placenta of patients with preeclampsia. J Clin Endocrinol Metab 2001;86:1313-17.

42. Wagner U, Wahle M, Moritz F, et al. Promoter polymorphisms regulating corticotrophinreleasing hormone transcription in vitro. Horm Metab Res 2006;38:69-75.

43. Budziszewska B, Jaworska-Feil L, Tetich M, et al. Regulation of the human corticotropin-releasing-hormone gene promoter activity by antidepressant drugs in Neuro-2A and AtT-20 cells. Neuropsychopharmacology 2004;29:785-94.
44. Basta-Kaim A, Budziszewska B, Jaworska-Feil L, et al. Antipsychotic drugs inhibit the human corticotropin-releasing-hormone gene promoter activity in neuro-2A cells an involvement of protein kinases. Neuropsychopharmacology 2006;31:853-65.

45. Habib KE, Weld KP, Rice KC, et al. Oral administration of a corticotropin-releasing hormone receptor antagonist significantly attenuates behavioral, neuroendocrine, and autonomic responses to stress in primates. Proc Natl Acad Sci USA 2000:97:6079-84.

46. Inder WJ, Prickett TC, Ellis MJ, et al. The utility of plasma $\mathrm{CRH}$ as a predictor of preterm delivery. J Clin Endocrinol Metab 2001;86:5706-10.

47. Baerwald CG, Mok CC, Fife MS, et al. Distribution of corticotropin-releasing hormone promoter polymorphism in different ethnic groups: evidence for natural selection in human populations. Immunogenetics 1999;49:894-9.

48. Phillips DI, Bennett Fl, Wilks R, et al. Maternal body composition, offspring blood pressure and the hypothalamic-pituitary-adrenal axis. Paediatr Perinat Epidemiol 2005; 19:294-302.

49. Levitt NS, Lambert EV, Woods D, et al. Impaired glucose tolerance and elevated blood pressure in low birth weight, nonobese, young south african adults: early programming of cortisol axis. J Clin Endocrinol Metab 2000;85:4611-18.

50. Dwyer T, Blizzard L, Morley R, et al. Within pair association between birth weight and blood pressure at age 8 in twins from a cohort study. BMJ 1999;319:1325-9.

51. Dwyer T, Blizzard L, Venn A, et al. Syndrome X in 8-y-old Australian children: stronger associations with current body fatness than with infant size or growth. Int J Obes Relat Metab Disord 2002;26:1301-9.

52. Dwyer T, Ponsonby AL, Newman NM, et al. Prospective cohort study of prone sleeping position and sudden infant death syndrome. Lancet 1991;337:1244-7.

53. Jones G, Dwyer T. Bone mass in prepubertal children: gender differences and the role of physical activity and sunlight exposure. J Clin Endocrinol Metab 1998;83:4274-9.

54. Dwyer T, Blizzard L, Ashbolt R, et al. Cutaneous melanin density of Caucasians measured by spectrophotometry and risk of malignant melanoma, basal cell carcinoma, and squamous cell carcinoma of the skin. Am J Epidemiol 2002;155:614-21.

55. Gonzalez-Gay MA, Hajeer AH, Dababneh A, et al. Corticotropin releasing hormone promoter polymorphisms in giant cell arteritis and polymyalgia rheumatica. Clin Exp Rheumatol 2002;20:133-8

56. Russ AP, Maerz W, Ruzicka V, et al. Rapid detection of the hypertension-associated Met235 $\rightarrow$ Thr allele of the human angiotensinogen gene. Hum Mol Genet 1993;2:609-10.

57. Ossendorf M, Prellwitz W. Rapid and easy apolipoprotein E genotyping using an improved PCR-RFLP technique. Qiagen News (Clinical) 2000;1:11-13.

58. Chiu KC, McCarthy JE. The insertion allele at the angiotensin I-converting enzyme gene locus is associated with insulin resistance. Metabolism 1997;46:395-9.

59. Morris JC, Bertram CE, Lowry PJ, et al. Cryptic trinucleotide repeat polymorphism in the POMC gene. Hum Mol Genet 1994;3:2080.

60. Agarwal AK, Giacchetti G, Lavery G, et al. CA-Repeat polymorphism in intron 1 of HSD11B2: effects on gene expression and salt sensitivity. Hypertension 2000;36:187-94.

61. Lavery GG, McTernan CL, Bain SC, et al. Association studies between the HSD11B2 gene (encoding human 11 beta-hydroxysteroid dehydrogenase type 2), type 1 diabetes mellitus and diabetic nephropathy. Eur J Endocrinol 2002;146:553-8.

62. Online Mendelian Inheritance in Man (OMIM). http://www.ncbi.nlm.nih.gov/ entrez/query.fcgi?CMD = search\&DB = omim (accessed 26 Jun 2008).

63. NCBI. http://www.ncbi.nlm.nih.gov/projects/SNP/ (accessed 26 Jun 2008).

64. GenBank. http://www.ncbi.nlm.nih.gov/Genbank/ (accessed 26 Jun 2008).

65. Hosmer D, Lemeshow S. Applied logistic regression. 2nd edn. New York: John Wiley \& Sons, 2000.

66. Tu Y-K, West R, Ellison GTH, et al. Why evidence for the fetal origins of adults disease might be a statistical artifact: the "reverse paradox" for the relation between birth weight and blood pressure in later life. Am J Epidemiol 2005;161:27-32.

67. Seckl JR, Meaney MJ. Glucocorticoid programming. Ann N Y Acad Sci 2004; 1032:63-84.

68. Economides DL, Nicolaides KH, Linton EA, et al. Plasma cortisol and adrenocorticotropin in appropriate and small for gestational age fetuses. Fetal Ther 1988;3:158-64.

69. Auchus RJ. Miscellaneous endocrine causes of hypertension. Curr Cardiol Rep 2005; 7:418-24. 


\section{APPENDIX}

Table AI Selected gene variants of interest in relation to skin pigmentation, birth weight and blood pressure

\begin{tabular}{|c|c|c|c|c|c|c|c|c|}
\hline & \multicolumn{8}{|c|}{ Gene (OMIM* reference) } \\
\hline & $\begin{array}{l}\text { ACE Chr17q23 } \\
(106180)\end{array}$ & $\begin{array}{l}\text { AGT Chr1q42- } \\
\text { q43 (106150) }\end{array}$ & $\begin{array}{l}\text { ApoE Chr 19q13.3 } \\
\text { (107741) }\end{array}$ & $\begin{array}{l}\text { PON2 Chr 7q21.3 } \\
\text { (602447) }\end{array}$ & $\begin{array}{l}\text { PC1 Chr } \\
6 q 22 q-23 \\
(173335)\end{array}$ & $\begin{array}{l}\text { POMC Chr 2p23.3 } \\
(176830)\end{array}$ & $\begin{array}{l}\text { 11ק-HSD2 Chr } \\
16 q 22(218030)\end{array}$ & $\begin{array}{l}\text { CRH Chr 8q13 } \\
(122560)\end{array}$ \\
\hline \multirow[t]{3}{*}{$\begin{array}{l}\text { Name of } \\
\text { measured } \\
\text { polymorphism }\end{array}$} & \multirow[t]{3}{*}{$\begin{array}{l}\text { ACE I/D, } 288 \text { bp } \\
\text { insertion (I)/ } \\
\text { deletion (D) in } \\
\text { intron } 16\end{array}$} & \multirow[t]{3}{*}{ AGT Met235Thr } & $\begin{array}{l}\text { APOE } \varepsilon 2, \varepsilon 3, \text { or } \varepsilon 4 \\
\varepsilon 2=112 \text { Cys/ } \\
158 \text { Cys }\end{array}$ & \multirow[t]{3}{*}{ P0N2 Ala148Gly } & \multirow[t]{3}{*}{$\begin{array}{l}\text { PC1 } \\
\text { Lys121Gln }\end{array}$} & \multirow[t]{3}{*}{$\begin{array}{l}\text { POMC I/D, } 9 \text { bp } \\
\text { insertion (I) or } \\
\text { deletion (D) in } \\
\text { exon } 3\end{array}$} & \multirow[t]{3}{*}{$\begin{array}{l}11 \beta-H S D 2\{C A\}_{n} \\
\text { repeat with short } \\
\text { alleles } \leqslant 236 \text { bp }\end{array}$} & \multirow[t]{3}{*}{$\begin{array}{l}\mathrm{CRH}+\mathrm{T} 1273 \mathrm{C} \text { in } \\
5^{\prime} \mathrm{UTR} \text { promoter }\end{array}$} \\
\hline & & & $\begin{array}{l}\varepsilon 3=112 \text { Cys/ } \\
158 \operatorname{Arg}\end{array}$ & & & & & \\
\hline & & & $\begin{array}{l}\varepsilon 4=112 \mathrm{Arg} / \\
158 \mathrm{Arg}\end{array}$ & & & & & \\
\hline \multirow{2}{*}{$\begin{array}{l}\text { (Reference NCBI } \\
\text { database SNP ID } \\
\text { or GenBank } \\
\text { Accession Code) }\end{array}$} & \multirow[t]{2}{*}{ (rs13447447) } & \multirow[t]{2}{*}{ (rs699) } & $\begin{array}{l}\text { Cys112Arg } \\
\text { (rs429358) }\end{array}$ & \multirow[t]{2}{*}{ (rs12026) } & \multirow[t]{2}{*}{ (rs1044498) } & \multirow[t]{2}{*}{ (rs10654394) } & \multirow[t]{2}{*}{$\begin{array}{l}\text { (GenBank } \\
\text { AF071493) }\end{array}$} & \multirow[t]{2}{*}{$\begin{array}{l}\text { (GenBank } \\
\text { x67661) }\end{array}$} \\
\hline & & & $\begin{array}{l}\text { Arg158Cys } \\
\text { (rs7412) }\end{array}$ & & & & & \\
\hline $\begin{array}{l}\text { Functional effect } \\
\text { of genetic variant }\end{array}$ & $\begin{array}{l}\text { Circulating ACE } \\
\text { levels highest in } \\
\text { ACE D/D } \\
\text { subjects, twice } \\
\text { that of ACE } \mathrm{I} / \mathrm{l} \text { and } \\
\text { intermediate in } \\
\text { ACE } \mathrm{I} / \mathrm{D}^{14} 15\end{array}$ & $\begin{array}{l}\text { Met235Thr } \\
\text { changes AGT } \\
\text { gene expression } \\
\text { and linked } \\
\text { hypertension in } \\
\text { some } \\
\text { populations. } \\
\text { Thr235Thr is the } \\
\text { ancestral form, } \\
\text { advantageous in } \\
\text { salt scarcity }^{20}\end{array}$ & $\begin{array}{l}\text { APOE variants } \\
\text { influence the } \\
\text { efficiency and type } \\
\text { of lipoprotein } \\
\text { carriage. The most } \\
\text { common (wild- } \\
\text { type) }=\varepsilon 3 / \varepsilon 33 \text {, } \\
\text { with } \varepsilon 4 \text { allele } \\
\text { associated with } \\
\text { higher serum } \\
\text { cholesterol }^{25}\end{array}$ & $\begin{array}{l}\text { PON2 hydrolyses } \\
\text { the products of } \\
\text { LDL oxidation, } \\
\text { related to HDL- } \\
\text { associated } \\
\text { cardioprotection. } \\
\text { Gly148Gly } \\
\text { associated with } \\
\text { higher mean } \\
\text { fasting plasma } \\
\text { glucose }^{28}\end{array}$ & $\begin{array}{l}\text { Allelic variants } \\
\text { change insulin } \\
\text { signalling at } \\
\text { the site of the } \\
\text { insulin } \\
\text { receptor. } \\
\text { Variants that } \\
\text { upregulate } \\
\text { PC1 inhibit } \\
\text { insulin } \\
\text { receptor } \\
\text { activity }\end{array}$ & $\begin{array}{l}\text { POMC gene } \\
\text { inactivation is } \\
\text { associated with } \\
\text { reduced ACTH and } \\
\text { MSH production. } \\
\text { The exon } 3 \\
\text { insertion is } \\
\text { associated with a } \\
\text { loss of POMC } \\
\text { function with I/D } \\
\text { having } 24 \% \text { higher } \\
\text { insulin than D/D } \\
\text { and also lower } \\
\text { insulin sensitivity }{ }^{35}\end{array}$ & $\begin{array}{l}\text { The } 11 \beta \text {-HSD2 } \\
\text { gene controls } \\
\text { enzyme activity for } \\
\text { the breakdown of } \\
\text { cortisol and related } \\
\text { products. Defects } \\
\text { in function result in } \\
\text { higher circulating } \\
\text { glucocorticoids. } \\
\text { Short alleles are } \\
\text { associated with } \\
\text { fewer CA(n) } \\
\text { repeats and } \\
\text { reduced enzyme } \\
\text { activity }\end{array}$ & $\begin{array}{l}\text { It has only } \\
\text { recently been } \\
\text { established that } \\
\text { CRH reactivity } \\
\text { varies between } \\
\text { promoter alleles. }^{42} \\
\text { Psychotropics } \\
\text { can inhibit the } \\
\text { CRH gene, }{ }^{43}{ }^{44} \text { so } \\
\text { a possible link to } \\
\text { dysregulated HPA } \\
\text { activity exists }\end{array}$ \\
\hline $\begin{array}{l}\text { Association } \\
\text { between genetic } \\
\text { variant and } \\
\text { disease }\end{array}$ & $\begin{array}{l}\mathrm{I} / \mathrm{D} \uparrow \text { insulin } \\
\text { resistance, } \uparrow \\
\text { cardiovascular } \\
\text { disease risk, } \\
\text { especially in } \\
\text { those with }_{\text {diabetes }^{16}{ }^{17}}\end{array}$ & $\begin{array}{l}\text { Thr235Thr is } \\
\text { related to salt- } \\
\text { sensitive } \\
\text { hypertension }^{21}\end{array}$ & $\begin{array}{l}\varepsilon 4 \text { allele is } \\
\text { associated with } \\
\text { adverse } \\
\text { dyslipidaemia, } \\
\text { particularly if } \varepsilon 4 / \varepsilon 4 \\
\text { (familial } \\
\text { dyslipidaemia type } \\
\text { V) }\end{array}$ & $\begin{array}{l}\text { Various PON2 } \\
\text { variants are } \\
\text { associated with } \\
\text { CHD risk, } \\
\text { Gly148Gly alleles } \\
\text { associated with } \\
\text { higher plasma } \\
\text { glucose levels } \\
\text { among diabetics }^{28}\end{array}$ & $\begin{array}{l}\text { 121Gln Variant } \\
\text { associated } \\
\text { with altered } \\
\text { insulin and } \\
\text { plasma } \\
\text { glucose after } \\
\text { oral glucose } \\
\text { test. } \\
\text { 121 } \\
\text { asson Variant } \\
\text { with primary } \\
\text { insulin } \\
\text { resistance in } \\
\text { Indians and } \\
\text { childhood } \\
\text { obesity }\end{array}$ & $\begin{array}{l}\text { POMC inactivation } \\
\text { is associated with } \\
\text { early onset obesity, } \\
\text { adrenal } \\
\text { insufficiency and } \\
\text { altered } \\
\text { pigmentation }^{36}\end{array}$ & $\begin{array}{l}\text { Essential } \\
\text { hypertension }{ }^{39} \text { and } \\
\text { salt-sensitive } \\
\text { hypertension }{ }^{40} \\
\text { associated with } \\
\text { reduced } 11 \beta \text {-HSD2 } \\
\text { activity }\end{array}$ & $\begin{array}{l}\text { HPA activation by } \\
\text { CRH is implicated } \\
\text { in stress-induced } \\
\text { hypertension and } \\
\text { cortisol-related } \\
\text { hypertension }^{45}\end{array}$ \\
\hline $\begin{array}{l}\text { Association } \\
\text { between genetic } \\
\text { variant and } \\
\text { perinatal factors }\end{array}$ & $\begin{array}{l}\text { In low birth } \\
\text { weight, ACE I } \\
\rightarrow \uparrow \text { adult insulin } \\
\text { secretion }^{18}\end{array}$ & $\begin{array}{l}\text { Thr235 allele } \\
\text { associated with } \\
\text { plasma } \\
\text { triglycerides in } \\
\text { neonates in } \\
\text { Trinidad }^{22}\end{array}$ & $\begin{array}{l}\text { Effect of APOE } \\
\text { genotype on LDL } \\
\text { levels was found to } \\
\text { be greater in low- } \\
\text { birthweight } \\
\text { babies }^{25}\end{array}$ & $\begin{array}{l}\text { Ala148Ala } \\
\text { genotype } \\
\text { associated with } \\
\text { low birth weight } \\
\text { in South Asians }{ }^{29}\end{array}$ & $\begin{array}{l}\text { In a Finnish } \\
\text { birth cohort, } \\
121 \mathrm{Gln} \text { allele } \\
\text { was } \\
\text { associated } \\
\text { with type } 2 \\
\text { diabetes in } \\
\text { babies of low } \\
\text { length } \\
\text { (<49 cm) but } \\
\text { not among } \\
\text { longer } \\
\text { infants }^{33}\end{array}$ & & $\begin{array}{l}\text { Reduced } 11 \beta \text {-HSD2 } \\
\text { is associated with } \\
\text { low birth weight } \\
\text { and hypertension }{ }^{41} \\
\text { Positive correlation } \\
\text { between placental } \\
\text { HSD11B2 activity } \\
\text { and birth weight }{ }^{41}\end{array}$ & $\begin{array}{l}\text { High CRH levels } \\
\text { at } 26 \text { weeks' } \\
\text { gestation are } \\
\text { associated with } \\
\text { subsequent } \\
\text { preterm delivery }\end{array}$ \\
\hline $\begin{array}{l}\text { Association } \\
\text { between genetic } \\
\text { variant and race } \\
\text { or skin } \\
\text { pigmentation }\end{array}$ & $\begin{array}{l}\text { Conflicting } \\
\text { results. ACE D } \\
\text { allele over- } \\
\text { represented in } \\
\text { Afro-Caribbean } \\
\text { compared with } \\
\text { caucasians }^{19}\end{array}$ & $\begin{array}{l}\text { Thr235 allele } \\
\text { more common in } \\
\text { dark skin } \\
\text { races. }{ }^{23}{ }^{20} \mathrm{M} \text { more } \\
\text { common in white } \\
\text { than Japanese }{ }^{24}\end{array}$ & $\begin{array}{l}\varepsilon 4 \text { allele is } \\
\text { associated with a } \\
\text { "thrifty" genotype } \\
\text { re food scarcity. In } \\
\text { Europeans, more } \\
\text { common for higher } \\
\text { latitude" }\end{array}$ & Not reported & $\begin{array}{l}121 \mathrm{Gln} \text { variant } \\
\text { higher in } \\
\text { Asians than } \\
\text { caucasians. } \\
\text { Prevalence } \\
\text { also high in } \\
\text { Dominican } \\
\text { republic }^{34}\end{array}$ & $\begin{array}{l}\text { POMC loss-of- } \\
\text { function mutations } \\
\text { result in a loss of } \\
\text { pigmentation }\end{array}$ & $\begin{array}{l}\text { Skin } \\
\text { melanogenesis, } \\
\text { stimulated by } \\
\text { glucocorticoids, } \\
\text { could be affected } \\
\text { by } 11 \beta \text {-HSD2 } \\
\text { activity because of } \\
\text { the build up of } \\
\text { cortisol }\end{array}$ & $\begin{array}{l}\mathrm{C} \text { gene is } \\
\text { ancestral form, } \\
\text { with T gene } \\
\text { having a higher } \\
\text { prevalence in } \\
\text { caucasians }(0.9) \\
\text { than Africans } \\
(0.3)^{47}\end{array}$ \\
\hline
\end{tabular}

